\title{
A Comparative Study on the Knowledge, Attitude, and Perception toward Hazardous Medical Waste Produced at Home in a Coastal City of Karnataka, India
}

\author{
Prajna Narayan ${ }^{1}$ Ankeeta Menona Jacob ${ }^{1}$ Pranav Shetty ${ }^{1}$ Preethika Singh ${ }^{1}$ \\ ${ }^{1}$ Department of Community Medicine, KS Hegde Medical Academy, \\ Mangalore, Karnataka, India \\ J Health Allied Sci ${ }^{\mathrm{NU}} 2022 ; 12: 126-133$. \\ Address for correspondence Ankeeta Menona Jacob, MD, DNB, \\ Department of Community Medicine, KS Hegde Medical Academy, \\ Nithyananda Nagar Post, Deralakatte 575018, Mangalore, Dakshina \\ Kannada District, Karnataka, India (e-mail: neelankeet@gmail.com).
}

Abstract

Keywords
- refuse disposal
- medical waste
disposal
- condoms
- menstrual hygiene
products
- domestic biomedical
waste

Introduction Hazardous healthcare waste produced at home contributes to approximately $0.5 \%$ of biomedical waste, and although potentially infectious, is often discarded with other domestic wastes. The study aimed to quantify and compare types and patterns of biomedical waste generated in homes and to assess the knowledge, attitude, and practices regarding biomedical waste among selected urban and rural households in the coastal area of Mangalore city in Karnataka.

Methods A cross-sectional study was conducted in households consisting of rural and urban field practice areas of a tertiary care hospital in coastal Karnataka from November 2017 to February 2018. A pretested semi-structured questionnaire on knowledge, attitude, and practice regarding healthcare waste generated at home was assessed. Qualitative variables of the waste segregation practice, types of biomedical waste, the knowledge, perception, and attitude to practices regarding biomedical waste were expressed in percentages proportions and analyzed using SPSS v.20.

Results Baby diapers were the most common hazardous waste. The number of baby diapers produced daily in rural and urban areas was 32 (42.7\%) and 64 (85.3\%), respectively. The urban households had better knowledge of possible hazardous healthcare waste at home, 28 (37.33\%) compared with 7 (9.3\%) in rural households. Seventy-one (94.7\%) urban and $49(65.3 \%)$ rural households had a favorable attitude toward the disposal of hazardous domestic biomedical waste.

Conclusion The knowledge, attitudes, and practices regarding hazardous healthcare waste produced at the household level were better among urban households compared with rural households.

\section{Introduction}

Biomedical waste is generated during the diagnosis, treatment, immunization of human beings or animals, research activities, and/or the production and testing of biologicals. ${ }^{1}$
Biomedical waste is mainly produced in hospitals, clinics, nursing homes, veterinary hospitals, and blood banks. Households are typically believed to produce little to no biomedical waste. ${ }^{1}$ Because of healthcare requirements, home diagnosable kits for diabetes and pregnancy, non-degradable sanitary
DOI https://doi.org/ $10.1055 / \mathrm{s}-0041-1736273$ ISSN 2582-4287.

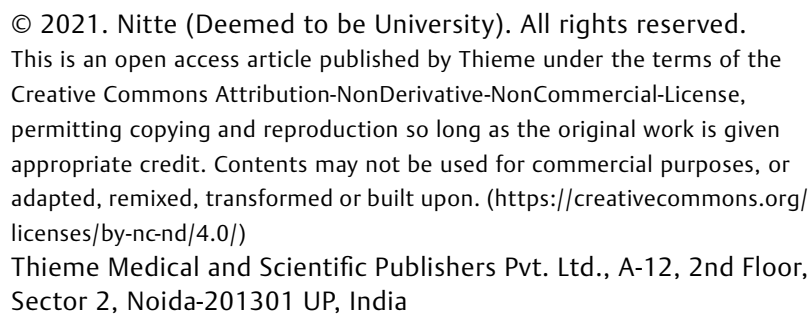


pads, toilet papers, bandages, baby diapers, and wipes are increasingly being made available to the public, resulting in a notable increase in the amount of hazardous healthcare waste in recent years and are now more commonly produced at houses. ${ }^{2}$ These hazards, though infectious, are discarded without proper disposal along with other domestic wastes. ${ }^{2}$ They can pose a threat by increasing the chance of infection to those who handle the waste and to the environment.

Domestic hazardous healthcare wastes contribute to approximately $0.5 \%$ of the entire biomedical waste. ${ }^{1,3} \mathrm{~A}$ few sources of hazardous healthcare waste produced at home include needles used for testing sugar levels and injecting insulin, urine-soiled bedsheets, expired medicines, used condoms, razor blades, urine pregnancy kits, blood sugar test strips, sanitary pads contaminated with blood, and mercury from a broken sphygmomanometer or thermometer. ${ }^{4}$ Sanitary waste is often used to describe the waste consisting of infant/adult diapers, sanitary napkins/pads, sanitary towels, tampons, and incontinence sheets. ${ }^{5}$ The recent Solid Waste Management Rules that came into effect in 2016, however, have classified only some of these biomedical wastes such as expired medicines, broken mercury thermometers, used needles and syringes, and contaminated gauze as domestic hazardous wastes. On the other hand, the used condoms, sanitary pads, and other absorbent materials used during menstruation have not been considered as biomedical waste. $^{6}$

A study was conducted in Ghana regarding the quantity of hazardous healthcare waste largely produced such as unwanted medicines and sharps and observed that individuals who believed in the notion of improper disposal of healthcare waste were three times more likely to report any waste disposal related injuries. ${ }^{7}$ In one report from Israel, less than $14 \%$ of individuals returned unused/expired medications to the health maintenance organization pharmacies. ${ }^{8}$ This study also highlighted that legislative measures for household medical waste disposal play an important role in the appropriate handling of these wastes. ${ }^{8}$ In India, as seen in Israel, no legislation regarding disposal of domiciliary medical waste exists and thus no segregation of waste occurs. The concept of domestic biomedical waste is not widespread in India. ${ }^{6}$ Furthermore, very few studies have been conducted on the quantum and procedures of disposing of domestic wastes. However, the difference between the methods of disposal in urban and rural areas is largely obscure. Therefore, there is an urgent need to investigate the factors contributing to these differences and how these differences could be resolved. This is important in policy decisionmaking to improve the implementation and consequently reduce the environmental and health hazards of improper domestic biomedical waste disposal in India. The present study aimed to quantify and compare the amount of biomedical waste generated in homes in terms of types and patterns of production among selected urban and rural households. This study also looked into the disparities in waste disposal between urban and rural families, as well as the variables that contribute to these discrepancies. This study also assessed the knowledge, attitudes, and practices regarding biomedical waste and the perception toward biomedical waste disposal among the selected urban and rural households in a coastal city of Karnataka.

\section{Materials and Methods}

\section{Study Setting, Design, and Sample Size}

A community-based, cross-sectional study was conducted on selected households residing for more than 6 months in the rural and urban practice areas of a tertiary medical college in coastal Karnataka. The urban practice area caters to a population of $\sim 70,000$ and the rural practice area caters to a population of $\sim 2,000$ with $\sim 710$ households. The study was conducted from November 2017 to February 2018. Purposive sampling of $\sim 150$ households (75 rural and 75 urban), based on a study conducted by Bhaskar et al, ${ }^{9}$ produced $\sim 7,500 \mathrm{~kg}$ of hospital biomedical waste in Mangalore city. Meenakshi ${ }^{1}$ determined that domestic households produced $\sim 0.5 \%$ of the total biomedical waste. Given that an average urban health center caters to 100,000 individuals, which is acquired from the national urban health mission implementation of urban health centers, ${ }^{10} \sim 75$ houses in rural and urban areas (150 households) were included in the study. The residents who were not available for interviews after three consecutive visits to the community were excluded from the study. The study protocol received approval from the Institutional Ethics Committee and clearance prior to the commencement of the study.

\section{Study Tool}

A pretested semi-structured questionnaire containing information on sociodemographic details, knowledge, attitudes, and practices regarding household biomedical waste production and disposal was utilized. The questionnaire contained 13 questions on knowledge. Each question with the correct choice was scored as 1 mark and the rest were scored as 0 . The knowledge of the household was scored as good (i.e., score 10 and above), average (7 to 9 ), and poor (less than or equal to 6). The questionnaire contained 6 questions on attitude and 4 on practice regarding hazardous biomedical waste generated at home. The attitude was scored as favorable when the score was more than 4 and scores less than 3 were scored unfavorable. The practice score was considered poor when the total score was less than or equal to 2 and good when the scores were more than 3 . The content validity of the study tool was ascertained after doing a pilot study among rural and urban households and making appropriate changes to the scoring of knowledge-, attitude-, and practice-related questions before the commencement of the main study. In the absence of previous quotable studies on knowledge, attitude, and practice on domestic biomedical waste in India, a scoring pattern, for knowledge, attitude, and practice was developed specifically for this study by the authors.

\section{Statistical Analysis}

Data were entered in MS Excel for analysis using SPSS (Statistical Package for Social Sciences) software v.20. 
Table 1 Frequency and pattern of hazardous healthcare waste in the population

\begin{tabular}{|c|c|c|c|c|c|c|}
\hline \multirow[t]{2}{*}{ Sources of hazardous healthcare waste at home } & \multicolumn{6}{|c|}{$\begin{array}{l}\text { Frequency of production } \\
N=150(\%)\end{array}$} \\
\hline & Area & Daily & Alternate day & Weekly & Monthly & Rarely/nil \\
\hline \multirow[t]{2}{*}{ Used pregnancy strip } & Rural & $0(0.0)$ & $9(12.0)$ & $14(18.7)$ & $20(26.7)$ & $32(42.7)$ \\
\hline & Urban & $4(5.3)$ & $3(4.0)$ & $12(16.0)$ & $3(4.0)$ & $53(70.7)$ \\
\hline \multirow[t]{2}{*}{ Baby diapers } & Rural & $32(42.7)$ & $7(9.3)$ & 14 (18.7) & $16(21.3)$ & $6(8.0)$ \\
\hline & Urban & $64(85.3)$ & $1(1.3)$ & $8(10.7)$ & $0(0.0)$ & $2(2.7)$ \\
\hline \multirow[t]{2}{*}{ Used razor blades } & Rural & $1(1.3)$ & $19(25.3)$ & $9(12.0)$ & $38(50.7)$ & $8(10.7)$ \\
\hline & Urban & $10(13.3)$ & $7(9.3)$ & $18(24.0)$ & $30(40.0)$ & $10(13.3)$ \\
\hline \multirow[t]{2}{*}{ Sanitary pads/menstrual-related material } & Rural & \multirow{2}{*}{\multicolumn{2}{|c|}{$0(0.0)$}} & \multirow[t]{2}{*}{$5(6.7)$} & 68 (90.7) & $2(2.7)$ \\
\hline & Urban & & & & 70 (93.3) & $0(0.0)$ \\
\hline \multirow[t]{2}{*}{ Used condoms } & Rural & \multirow{2}{*}{\multicolumn{2}{|c|}{$0(0.0)$}} & $20(26.7)$ & $31(41.3)$ & $24(32.0)$ \\
\hline & Urban & & & $8(10.7)$ & $25(33.3)$ & $42(56.0)$ \\
\hline \multirow[t]{2}{*}{ Lancets } & Rural & \multirow[t]{2}{*}{$1(1.3)$} & $7(9.3)$ & $25(33.3)$ & $11(14.7)$ & $31(41.3)$ \\
\hline & Urban & & $12(16.0)$ & $27(36.0)$ & $21(28.0)$ & $14(18.7)$ \\
\hline \multirow[t]{2}{*}{ Used bandages/dressings } & Rural & $1(1.3)$ & $5(6.7)$ & $3(4.0)$ & $9(12.0)$ & $57(76.0)$ \\
\hline & Urban & \multicolumn{2}{|l|}{$0(0.0)$} & $4(5.3)$ & $6(8.0)$ & $65(86.7)$ \\
\hline \multirow[t]{2}{*}{ Expired medicines } & Rural & $0(0.0)$ & $5(6.7)$ & $1(1.3)$ & $21(28.0)$ & $48(64.0)$ \\
\hline & Urban & \multicolumn{2}{|l|}{$0(0.0)$} & $4(5.3)$ & $7(9.3)$ & 64 (85.4) \\
\hline
\end{tabular}

Note: Values in bold represent the highest percentages.

Qualitative variables of the duration of residence, waste segregation practices, types of biomedical waste, knowledge, perception, and attitude to practices regarding biomedical waste were expressed in percentages and proportions. The association of knowledge, attitude, and practice levels among rural and urban households was determined using the Chi-square test. The factors associated $(p<0.10)$ with each of the domains were subjected to multiple logistic regression after which the significant factors contributing to knowledge, attitude, and practice domains in urban and rural areas were found to be substantial.

\section{Results}

\section{General Solid Waste Disposal Practices of Study Populations}

In our study, 113 (75.3\%) households reported that they disposed of domestic wastes daily; 69 (92.0\%) households in urban areas disposed of garbage daily since the waste collection procedure was conducted by the municipal and local authorities. However, in the rural study population, daily disposal of domestic waste was seen in only 44 households (58.7\%) and was found to differ significantly from urban households. The presence of garbage collection bins was more common in rural households 69 (92.0\%) than urban households 56 (74.7\%); this significant difference could be because of more coverage of garbage disposal facilities in urban areas than in rural areas.

\section{Production of Hazardous Healthcare Wastes in Study Populations}

The frequency and pattern of production of these hazardous healthcare wastes at home are shown in - Table 1. The most produced hazardous healthcare waste was baby diapers in rural and urban areas, which were produced daily, i.e., by 32 houses (42.7\%) and 64 (85.3) houses, respectively. Hazardous healthcare wastes such as strips for urine pregnancy tests, lancets, bandages/dressings, and expired medicines were produced rarely, whereas sanitary pads/menstrual-related material and used condoms were frequently produced on a monthly basis, which was seen largely in urban areas than in rural areas. In urban settings, the frequency of production of lancets and blades was more common weekly (27 [36.0\%]) and monthly (21 [28.0\%]) when compared with rural areas which rarely produced lancets (31 [41.3\%]).

\section{Knowledge about Hazardous Healthcare Waste Produced at Home}

- Table 2 shows the level of knowledge regarding hazardous healthcare waste in urban and rural areas. Approximately 50 (66.7\%) households in urban areas knew about hazardous healthcare waste when compared with 29 (38.7\%) in rural households. Around 41 (64.1\%) of urban households knew that hazardous healthcare waste is perilous, which was much higher than the $23 \%$ of rural households (35.9\%). The knowledge of biomedical waste disposal was found to be significantly higher among urban households than in rural households (-Table 2 ). The knowledge regarding sources 
Table 2 Knowledge about hazardous healthcare waste $(N=150)$

\begin{tabular}{|c|c|c|c|c|c|}
\hline \multicolumn{2}{|l|}{ Questions } & \multicolumn{2}{|c|}{ Frequency $n(\%)$} & \multirow{4}{*}{$\begin{array}{l}t \text {-Value } \\
11.794\end{array}$} & \multirow{4}{*}{$\begin{array}{l}p \text {-Value } \\
0.001^{\mathrm{a}}\end{array}$} \\
\hline & & Yes & No & & \\
\hline \multirow[t]{2}{*}{ Heard of hazardous healthcare waste } & Rural & $29(38.7)$ & $46(61.3)$ & & \\
\hline & Urban & $50(66.7)$ & $25(33.3)$ & & \\
\hline \multirow[t]{2}{*}{ Knowledge about biomedical waste disposal } & Rural & $32(47.8)$ & $43(51.8)$ & \multirow[t]{2}{*}{0.243} & \multirow[t]{2}{*}{0.622} \\
\hline & Urban & $35(52.2)$ & $40(48.2)$ & & \\
\hline \multirow[t]{2}{*}{ Hazards associated with improper healthcare waste disposal } & Rural & $23(35.9)$ & $52(60.5)$ & \multirow[t]{2}{*}{8.830} & \multirow[t]{2}{*}{$0.003^{\mathrm{a}}$} \\
\hline & Urban & $41(64.1)$ & $34(39.5)$ & & \\
\hline \multirow{2}{*}{$\begin{array}{l}\text { Observance of safety precautions when } \\
\text { handling hazardous healthcare waste }\end{array}$} & Rural & $18(24.0)$ & $57(76.0)$ & \multirow[t]{2}{*}{12.45} & \multirow[t]{2}{*}{$<0.001^{\mathrm{b}}$} \\
\hline & Urban & $3(4.0)$ & $72(96.0)$ & & \\
\hline \multicolumn{6}{|l|}{ Knowledge regarding the following as biomedical waste } \\
\hline \multirow[t]{2}{*}{ Urine pregnancy strips } & Rural & $26(34.7)$ & $49(65.3)$ & \multirow[t]{2}{*}{2.238} & \multirow[t]{2}{*}{0.135} \\
\hline & Urban & $35(46.7)$ & $40(53.3)$ & & \\
\hline \multirow[t]{2}{*}{ Baby diapers } & Rural & $48(39.3)$ & $27(36.0)$ & \multirow[t]{2}{*}{29.684} & \multirow[t]{2}{*}{$<0.001^{b}$} \\
\hline & Urban & $74(98.7)$ & $1(1.3)$ & & \\
\hline \multirow[t]{2}{*}{ Used razor blades } & Rural & $37(49.3)$ & $38(50.7)$ & \multirow[t]{2}{*}{9.108} & \multirow[t]{2}{*}{0.002} \\
\hline & Urban & $55(73.3)$ & $20(26.7)$ & & \\
\hline \multirow[t]{2}{*}{ Sanitary pads } & Rural & $38(50.7)$ & $37(49.3)$ & \multirow[t]{2}{*}{17.28} & \multirow[t]{2}{*}{$<0.001^{\mathrm{b}}$} \\
\hline & Urban & $62(82.7)$ & $13(17.3)$ & & \\
\hline \multirow[t]{2}{*}{ Lancet } & Rural & $20(26.7)$ & $55(66.3)$ & \multirow[t]{2}{*}{19.664} & \multirow[t]{2}{*}{$<0.001^{b}$} \\
\hline & Urban & $47(62.7)$ & $28(37.3)$ & & \\
\hline \multirow[t]{2}{*}{ Used bandages } & Rural & $51(68.0)$ & $24(32.0)$ & \multirow[t]{2}{*}{0.515} & \multirow[t]{2}{*}{0.473} \\
\hline & Urban & $55(73.3)$ & $20(26.7)$ & & \\
\hline Expired medicines & Rural & $31(41.3)$ & $44(58.7)$ & 9.689 & 0.002 \\
\hline & Urban & $50(61.7)$ & $25(33.3)$ & & \\
\hline Used condoms & Rural & $12(16.0)$ & $63(84.0)$ & 49.87 & $<0.001^{\mathrm{b}}$ \\
\hline & Urban & $55(73.3)$ & $20(26.7)$ & & \\
\hline
\end{tabular}

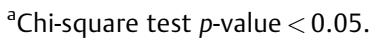

bischer's exact test $p$-value $<0.001$.

of biomedical waste generated at households was significantly higher among urban households when compared with rural households. The knowledge regarding hazardous biomedical waste produced at home (i.e., baby diapers) was reported by the majority of households 122 (81.3\%), and $\sim 106$ (70.7\%) of households considered sanitary pads and other menstruation-related products as hazardous healthcare waste. In contrast, less knowledge regarding hazardous healthcare waste was found among the study population for items including used pregnancy strips (61 [40.7\%]), condoms (67 [44.7\%]), lancets/blades (67 [44.7\%]), and expired medicines (81 [54.0\%]). A significantly higher number of urban households considered used condoms, baby diapers, sanitary pads, and other menstruation-related products and lancets as hazardous healthcare waste when compared with rural households. The urban households had better knowledge regarding possible hazardous healthcare waste at home, i.e., 28 (37.33\%) compared with 7 (9.3\%) rural households (-Fig. 1).

\section{Attitude toward Disposal of Hazardous Healthcare Waste in Study Populations}

As shown in - Table 3, 70 (93.3\%) families in urban areas concurred that it was suitable to utilize an alternate canister to gather the biomedical waste created at home, whereas only 42 (56.0\%) families in rural areas agreed with this. In addition, 58 (76.3\%) urban households agreed that it was not safe to dispose of hazardous healthcare waste along with domestic garbage as compared with 21 (28.0\%) rural households; and 69 (92.0\%) urban households agreed that incorrect disposal was unsafe for the environment and increased the risk of infection as compared with 56 (74.6\%) rural households. Overall, 64 (85.6\%) urban households believed in the disposal of hazardous healthcare waste if the facilities were provided as compared with 59 (78.7\%) rural households. Also, 59 (78.7\%) rural and 72 (96.0\%) urban households were in favor of adopting the practices of hazardous healthcare waste segregation. As shown in - Fig. 1, 71 (94.7\%) urban households and 49 (65.3\%) rural households had a favorable 


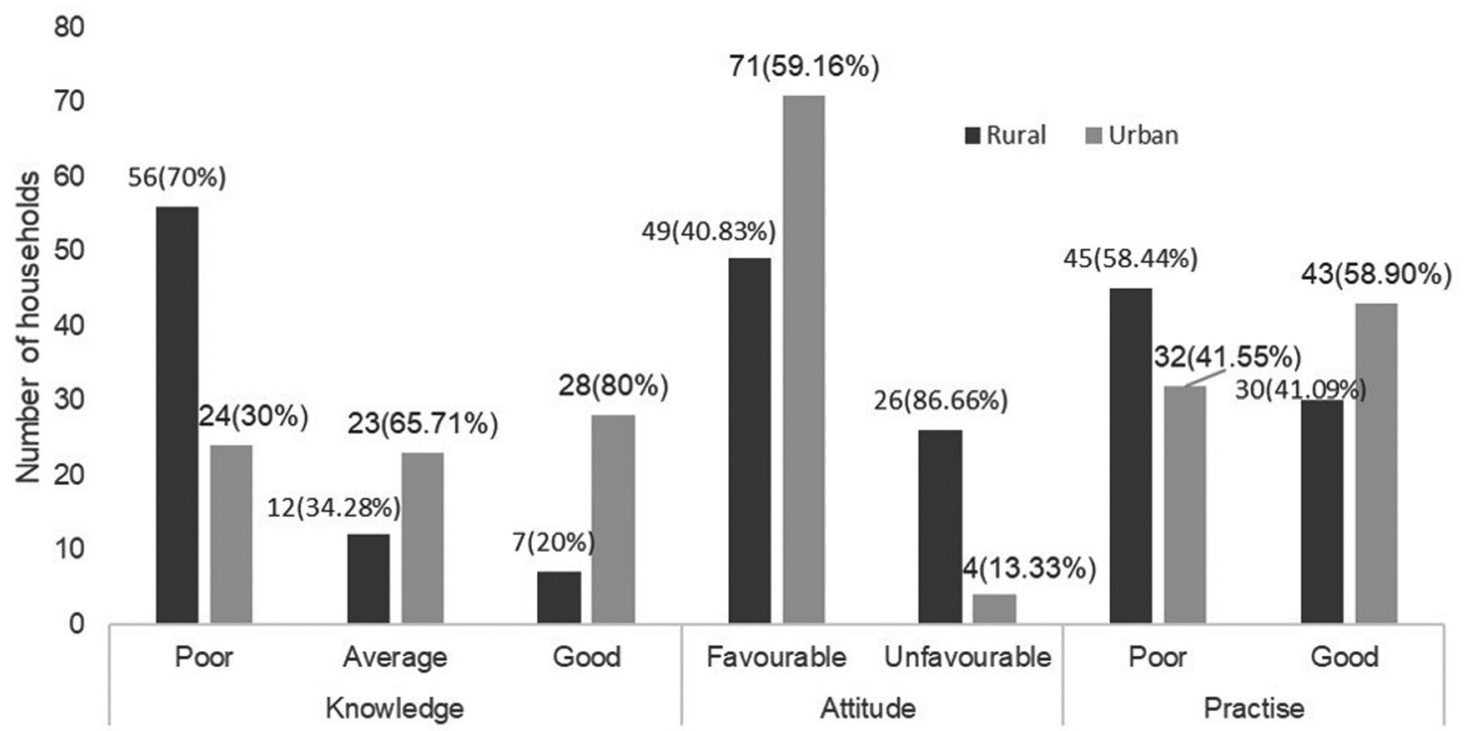

Knowledge, attitude and practise scores

Fig. 1 Comparison of knowledge, attitude, and practice of domestic waste disposal in urban and rural households of the study population.

Table 3 Comparison of attitudes regarding domestic waste disposal in urban and rural households of the study population $(N=150)$

\begin{tabular}{|c|c|c|c|c|c|c|}
\hline \multirow[t]{2}{*}{ Question } & \multirow[t]{2}{*}{ Area } & \multicolumn{5}{|l|}{ Frequency $n(\%)$} \\
\hline & & Strongly agree & Agree & Neutral & Disagree & Strongly disagree \\
\hline \multirow{2}{*}{$\begin{array}{l}\text { Is it appropriate to use a differ- } \\
\text { ent bin to dispose of hazardous } \\
\text { healthcare waste? }\end{array}$} & Rural & $18(24.0)$ & $24(32.0)$ & $16(21.3)$ & $11(14.7)$ & $6(8.0)$ \\
\hline & Urban & $44(58.7)$ & $26(34.7)$ & $3(4.0)$ & $2(2.7)$ & $0(0.0)$ \\
\hline \multirow{2}{*}{$\begin{array}{l}\text { Is it safe if biomedical waste is } \\
\text { disposed of along with garbage? }\end{array}$} & Rural & $17(22.7)$ & $24(32.0)$ & $13(17.3)$ & $13(17.3)$ & $8(10.7)$ \\
\hline & Urban & $3(4.0)$ & $5(6.7)$ & $9(12.0)$ & $37(49.3)$ & $21(28.0)$ \\
\hline \multirow{2}{*}{$\begin{array}{l}\text { Does incorrect disposal of bio- } \\
\text { medical waste make the envi- } \\
\text { ronment unsafe and other } \\
\text { people at risk of infections? }\end{array}$} & Rural & $24(32.0)$ & $32(42.7)$ & $13(17.3)$ & $4(5.3)$ & $2(2.7)$ \\
\hline & Urban & $47(62.7)$ & $22(29.3)$ & $3(4.0)$ & $2(2.7)$ & $1(1.3)$ \\
\hline \multirow{2}{*}{$\begin{array}{l}\text { Will the availability of facilities to } \\
\text { dispose of hazardous healthcare } \\
\text { waste help in decreasing hazards } \\
\text { associated with improper dis- } \\
\text { posal of hazardous healthcare } \\
\text { waste? }\end{array}$} & Rural & $14(18.7)$ & $39(52.0)$ & $21(28.0)$ & $1(1.3)$ & $0(0.0)$ \\
\hline & Urban & $36(48.0)$ & $28(37.3)$ & $6(8.0)$ & $3(4.0)$ & $2(2.7)$ \\
\hline \multirow{2}{*}{$\begin{array}{l}\text { Is the issue of biomedical waste } \\
\text { management significant to you? }\end{array}$} & Rural & $23(30.7)$ & $36(48.0)$ & $14(18.7)$ & \multirow[t]{2}{*}{$2(2.7)$} & $0(0.0)$ \\
\hline & Urban & $20(26.7)$ & $35(46.7)$ & $17(22.7)$ & & $1(1.3)$ \\
\hline \multirow{2}{*}{$\begin{array}{l}\text { If facilities for scientific disposal } \\
\text { of domestic waste are made } \\
\text { available, will you adopt the } \\
\text { practices of hazardous health- } \\
\text { care waste segregation? }\end{array}$} & Rural & $29(38.7)$ & $30(40.0)$ & $16(21.3)$ & \multirow{2}{*}{\multicolumn{2}{|c|}{$0(0.0)$}} \\
\hline & Urban & $49(65.3)$ & $23(30.7)$ & $3(4.0)$ & & \\
\hline
\end{tabular}

Note: Values in bold indicate the highest percentages. 
attitude toward the disposal of hazardous domestic biomedical waste, and the differences in favorable attitudes toward disposal were found to be statistically significant.

\section{Practices of Hazardous Healthcare Waste Collection and Disposal}

Around 55 (36.7\%) urban and 37 (49.3\%) rural households collected and disposed of hazardous healthcare waste separately. Though no significant differences were observed in the use of protective equipment when segregating hazardous healthcare waste, a higher number of urban households (46 [30.7\%]) used some protective equipment when disposing of hazardous healthcare waste ( - Table 4 ). Good practices concerning domestic medical waste collection and disposal were seen in 43 (57.3\%) urban households and 30 (40.0\%) rural households; these differences were also found to be statistically significant.

\section{Factors Affecting the Knowledge and Practices regarding Hazardous Household Biomedical Wastes Produced at Home}

The regression analysis showed that the knowledge regarding used condoms and diapers was significantly higher among urban households compared with rural households (-Table 5). The factors including frequent disposal of solid waste, use of personal protective equipment while handling and disposing biomedical waste at home were found to be significantly associated with urban than rural households.

\section{Discussion}

The present study evaluated the knowledge, attitudes, and practices with regard to healthcare wastes produced in urban and rural households of a coastal city of Karnataka. It also compared the practices regarding the domestic

Table 4 Comparison of practices of hazardous healthcare waste production in the study populations $(N=150)$

\begin{tabular}{|c|c|c|c|c|}
\hline \multirow[t]{2}{*}{ Hazardous healthcare waste practice } & \multicolumn{4}{|c|}{ Frequency $\mathrm{n}(\%)$} \\
\hline & Rural & Urban & $t$-Value & $p$-Value \\
\hline \multicolumn{5}{|l|}{ Waste collection practices } \\
\hline Separate bin for collection and separate disposal of the same & $37(49.3)$ & $55(36.7)$ & \multirow[t]{3}{*}{-} & \multirow[t]{3}{*}{-} \\
\hline Segregate but add with domestic waste & $25(16.7)$ & $20(13.3)$ & & \\
\hline No segregation practices followed & $13(8.7)$ & $0(0.0)$ & & \\
\hline Presence of waste collection bin & $56(74.7)$ & $69(92.0)$ & 8.402 & $0.038^{*}$ \\
\hline \multicolumn{5}{|l|}{ Frequency of disposing garbage } \\
\hline Daily & $69(92.0)$ & $44(58.7)$ & \multirow[t]{2}{*}{23.67} & \multirow[t]{2}{*}{$<0.001^{* *}$} \\
\hline Once in 2 days or more & $6(16.2)$ & $31(41.3)$ & & \\
\hline $\begin{array}{l}\text { Use personal protective equipment when segregating } \\
\text { domestic biomedical waste }\end{array}$ & $36(24.0)$ & $40(26.7)$ & 0.427 & 0.514 \\
\hline $\begin{array}{l}\text { Use personal protective equipment when disposing } \\
\text { of domestic biomedical waste }\end{array}$ & $20(13.3)$ & $46(30.7)$ & 18.29 & $<0.001^{* *}$ \\
\hline
\end{tabular}

$t$-value Chi square test. ${ }^{*}$-value $<0.05,{ }^{* *} p$-value $<0.001$.

Table 5 Multiple logistic regression factors affecting knowledge and practices in urban and rural households

\begin{tabular}{|c|c|c|c|c|c|}
\hline Domain & $\begin{array}{l}\text { Factors affecting the domains in } \\
\text { urban and rural households }\end{array}$ & $\begin{array}{l}\text { Unadjusted } \\
t \text {-value }\end{array}$ & $p$-Value & $\begin{array}{l}\text { Adjusted } \\
t \text {-value }\end{array}$ & $p$-Value \\
\hline Knowledge & Heard of hazardous healthcare waste & 11.794 & 0.001 & 1.542 & 0.214 \\
\hline \multirow[t]{6}{*}{ Source of biomedical waste } & Baby diapers & 29.684 & $<0.001$ & 14.67 & $<0.001$ \\
\hline & Used razor & 9.108 & 0.002 & 0.47 & 0.493 \\
\hline & Sanitary pads & 17.28 & $<0.001$ & 1.956 & 0.162 \\
\hline & Lancets & 19.664 & $<0.001$ & 0.019 & 0.89 \\
\hline & Used condoms & 49.87 & $<0.001$ & 24.575 & $<0.001$ \\
\hline & Expired medicines & 9.689 & 0.002 & 0.539 & 0.463 \\
\hline \multirow[t]{3}{*}{ Practice } & Presence of waste collection bins & 8.402 & 0.038 & 0.552 & 0.907 \\
\hline & Frequency of disposing garbage & 23.67 & $<0.001$ & 11.494 & 0.001 \\
\hline & $\begin{array}{l}\text { Use of personal protective equipment when } \\
\text { disposing domestic biomedical waste }\end{array}$ & 18.29 & $<0.001$ & 18.06 & $<0.001$ \\
\hline
\end{tabular}

Note: $t$-value-Pearson's Chi square; $p$-value $<0.05$. 
biomedical waste produced in rural and urban households. Our study showed that baby diapers constituted the hazardous waste produced daily in urban and rural households. The hazardous domestic waste produced monthly consisted of used razor blades, sanitary pads, and other menstrual fluid absorbent materials. The urban households had better knowledge, more favorable attitudes, and better hazardous waste handling practices compared with the rural households

There were significant disparities in waste disposal between urban and rural families, as well as the variables that contributed to these discrepancies. This might be because medical students or healthcare personnel frequently visit urban families and educate them, whereas rural areas have limited access, which could be a contributing factor to the lack of awareness. Furthermore, people in rural areas are frequently less informed about these issues than those in urban areas. In comparison to metropolitan regions, people living in rural areas have limited or no facilities for collecting and disposing of hazardous waste.

A study conducted in Ghana ${ }^{7}$ showed that $80 \%$ of the unwanted/discarded medicines and $89 \%$ of sharps were disposed of along with solid waste produced at home, of which $23 \%$ and $35 \%$ of respondents discarded the same without a container. The rates were higher compared with our study where discarded medicines and lancets were produced rarely and $\sim 92(61.33 \%)$ households used separate bins for collection and disposal of biomedical wastes.

Another study from Brazil ${ }^{11}$ showed that the sharps collected from households constituted $0.02 \pm 0.02 \%$ of the waste, whereas non-sharp weights accounted for $5.47 \pm 1.11 \%$ of the waste amounting to $5.29 \pm 1.13 \%$ of the total solid waste generated at the household level. Pertaining to sharp wastes, razor blades were discernible, whereas among the non-sharps stereotypically included toilet papers, diapers, and sanitary napkins which were in contrast to the study by Meenakshi ${ }^{1}$ who estimated the total content to be $\sim 0.5 \%$. This major difference could be because of the ablution habits of these two countries (Brazil and India), as toilet paper $(3.00 \pm 0.9 \%)$ was the most common domestic biomedical waste produced. In the present study, the most common domiciliary biomedical waste produced was baby diapers, which were produced daily followed by razor blades, sanitary pads/menstrual-related material, and used condoms, which accounted for the monthly waste.

In another study from Guinea, ${ }^{12} 43.6 \%$ of the households did not dispose of baby diapers along with solid waste, although $122(81.3 \%)$ of households knew that baby diapers were hazardous. According to a commentary by Sachdeva ${ }^{5}$, the sanitary waste produced in India was minimal compared with the sanitary waste generated in other countries, which was likewise in our study where most of the sanitary waste such as sanitary pads, used condoms, and menstruationrelated clothes/towels were produced monthly or rarely.

This study has many strengths. First, there are very few community-based studies on domestic waste management in India. Second, it is an understanding that the production of biomedical waste occurs mostly in healthcare settings, and we often defer from other areas such as domestic production. Third, this study highlights the unfocused areas of production of biomedical waste and the knowledge, attitude, and practice gap among the domestic pool consisting of urban and rural households in a coastal city of Karnataka. By this study, we recognize that we must focus on these areas of the community that will help us to detect, educate, and improve public health and prevent unnecessary consequences resulting from the hazards of the domestic biomedical waste output.

Our study also has certain limitations. The sample size was relatively small. The study participants were residing in the rural and urban field practice areas of the medical college, where medical students conducted health education sessions that may have influenced the segregation and waste disposal practices.

\section{Conclusion}

When quantification and assessment of the waste were accomplished, the most daily generated waste was baby diapers. In contrast, other sanitary wastes such as used condoms, menstruation-related particles, razor blades, and lancets were more commonly generated once a month. The segregation and disposal of such wastes were more among urban than rural households. The urban households had better knowledge and attitude toward hazardous healthcare waste segregation and disposal compared with rural households. The attitude was surprisingly affirmative to adopt proper segregation practices and facilities to correctly dispose of the biomedical waste produced at home. Regarding the practices, we observed that a significant number of houses adopted segregation practices, and urban households had used some form of protection when disposing of the waste. Performing this study helped us gain insights into the knowledge, attitude, and perception toward biomedical waste disposal among the selected rural and urban households in a coastal city of Karnataka.

\section{Conflict of Interest}

None declared.

\section{References}

1 Meenakshi P. Elements of Environmental Science and Engineering. 2nd ed. New Delhi: Prentice-Hall of India; 2012:324

2 Chaves LC, de Campos LMD, Filipini R, et al. Potentially hazardous waste produced at home. Int Arch Med 2013;6(01):27

3 Manasi S, Uma Mani KLatha. Biomedical Waste Management: Issues and Concerns - A Ward Level Study of Bangalore City. 1st ed. Vol. 1 Bangalore: The Institute for Social and Economic Change; 2014:26

4 Sharma A. Toxics alert: malady of household biomedical waste new awakening beckons? Toxics Alert-an environment news bulletin [Internet]. 2013; 45. Accessed December 1, 2018 at: http://enews.toxicslink.org/feature-view.php?id=24

5 Sachdeva S. Biomedical waste and solid waste management draft rules, 2015: a comment. Int J Health Allied Sci 2016;5(02): 129-132

6 Toolkit for implementation of solid waste management rules, 2016 [Internet]. Central Pollution Control Board 2017. Accessed October 30 
2019 at: http://www.npcindia.org.in/npc/Files/delhiOFC/EM/Toolkitkit-on-Solid-waste-management.pdf

7 Udofia EA, Gulis G, Fobil J. Solid medical waste: a cross sectional study of household disposal practices and reported harm in Southern Ghana. BMC Public Health 2017;17(01):464

8 Barnett-Itzhaki Z, Berman T, Grotto I, Schwartzberg E. Household medical waste disposal policy in Israel. Isr J Health Policy Res 2016;5(48):48

9 Bhaskar B, Nidugala H, Avadhani R. Biomedical waste management-knowledge and practices among healthcare providers in Mangalore. Nitte Univ J Health Sci 2012;2(01):35-36
10 National Urban Health Mission. National Health Mission, Department of Health and Family Welfare, Ministry of Health and Family Welfare, Government of India. Accessed July 28, 2021 at: http:// nhm.gov.in/index1.php?lang=1\&level=1\&sublinkid=970\&lid=137

11 Cussiol Nde M, Rocha GHT, Lange LC. Gravimetric characterization of potentially infectious material in urban solid waste in southern Belo Horizonte, Minas Gerais State, Brazil [Article in Portuguese]. Cad Saude Publica 2006;22(06):1183-1191

12 Mamady K. Factors influencing attitude, safety behavior, and knowledge regarding household waste management in Guinea: a cross-sectional study. J Environ Public Health 2016;2016:9305768 